\title{
Evaluation of the Anticipated Burden of COVID-19 on Hospital-Based Healthcare Services Across the United States
}

Rohan Khera MD MS $;^{1}$ Snigdha Jain MD; ${ }^{2}$ Zhenqiu Lin PhD; ${ }^{3,4}$ Joseph S. Ross MD MHS, ${ }^{4,5}$ Harlan M Krumholz MD SM ${ }^{3,4,6}$

${ }^{1}$ Department of Internal Medicine, Division of Cardiology, University of Texas Southwestern Medical Center, Dallas, TX

${ }^{2}$ Department of Internal Medicine, Division of Pulmonary and Critical Care, University of Texas Southwestern Medical Center, Dallas, TX

${ }^{3}$ Center for Outcomes Research and Evaluation, Yale-New Haven Hospital, New Haven, CT

${ }^{4}$ Section of Cardiovascular Medicine, Department of Internal Medicine, Yale School of Medicine, New Haven, CT

${ }^{5}$ Section of General Medicine, Department of Internal Medicine, Yale School of Medicine, New Haven, CT

${ }^{6}$ Department of Health Policy and Management, Yale School of Public Health, New Haven, CT

\section{Correspondence to:}

Dr. Rohan Khera; 5323 Harry Hines Blvd, E5.730, Dallas, TX - 75219

214-645-7521; rohankhera@outlook.com

or

Dr. Harlan M Krumholz; 1 Church St., Suite 200, New Haven, CT 06510

203-764-5885; harlan.krumholz@yale.edu

Word count: 600 


\section{Background}

Coronavirus disease-19 (COVID-19) is a global pandemic, with the potential to infect nearly $60 \%$ of the population. ${ }^{1}$ The disease is associated with high morbidity and mortality and current estimates are that nearly $20 \%$ of patients require hospitalization, $5 \%$ critical care. ${ }^{2,3}$ Over the past 2 months, multiple countries have witnessed their healthcare systems being overwhelmed by patients infected by COVID-19. The first case was diagnosed in the United States on January 21, 2020, but it has spread rapidly across the US. ${ }^{4,5}$ The anticipated spread of the virus requires an urgent appraisal of the capacity of US healthcare services and the identification of states most vulnerable to exceeding their capacity.

\section{Methods}

We evaluated state-level variation in bed capacity and ICU bed availability, and the state population requiring hospitalization that would saturate healthcare services. In the American Hospital Association survey for 2018, a database of US community hospitals, we identified total inpatient beds, adult intensive care unit (ICU) beds, and airborne isolation rooms across all hospitals in each state of continental US. The bed occupancy rate was defined as the daily average patient-days per hospital bed. We normalized our estimates against 2018 US Census estimates. The burden of COVID-19 hospitalizations was estimated based on a median hospitalization duration of 12 days, ${ }^{3}$ and was evaluated for a 30-day reporting period. All statistics are descriptive and were calculated using Stata 16. 


\section{Results}

In 2018, there were 5155 US community hospitals across 48 states in contiguous US and Washington DC, with a total of 788,032 inpatient beds, 68,280 adult ICU beds, and 44,222 isolation rooms. The median daily bed occupancy was $62.8 \%$ (IQR $58.1 \%$, $66.6 \%)$ across states. Nationally, for every 10,000 individuals, there are 24.2 inpatient beds, 2.8 adult ICU beds, and 1.4 isolation beds.

There is a 3-fold variation in the number of inpatient beds available across the US, ranging from 16.4 per 10,000 in Oregon to 47 per 10,000 in South Dakota (Figure 1). There was also a similar 3-fold variation in available or non-occupied beds, ranging from 4.7 per 10,000 in Connecticut through 18.3 per 10,000 in North Dakota. The availability of ICU beds is low nationally, ranging from 1.4 per 10,000 in Nevada to 4.7 per 10000 in Washington DC.

Hospitalizations for COVID-19 in a median $0.2 \%$ (IQR $0.2 \%, 0.3 \%$ ) of state population (Figure 2$)$, or $1.4 \%$ of state's older adults $(1.0 \%, 1.9 \%)$ will require all nonoccupied beds. Further, a median $0.6 \%(0.5 \%, 0.8 \%)$ of state population, or $3.9 \%$ $(3.1 \%, 4.6 \%)$ of older individuals would require $100 \%$ of inpatient beds. States of Vermont, Wyoming, Delaware, and Rhode Island would exceed their capacity with 2000 hospitalizations in a month, while Texas, California and Florida can each accommodate nearly 50 thousand patients in their available capacity.

\section{Discussion}

The COVID-19 pandemic is likely to overwhelm the limited number of inpatient and ICU beds for the US population. Hospitals in half of US states would exceed capacity if less 
medRxiv preprint doi: https://doi.org/10.1101/2020.04.01.20050492; this version posted April 3, 2020. The copyright holder for this preprint (which was not certified by peer review) is the author/funder, who has granted medRxiv a license to display the preprint in perpetuity. It is made available under a CC-BY-ND 4.0 International license.

than $0.2 \%$ of state population requires hospitalization in any given month. These are equivalent to rates observed in Wuhan, China, 1\% of the population was affected, 1 in 5 of whom required hospitalization. ${ }^{2}$

The study has certain limitations. We assume that all beds can be used to care for patients infected by COVID-19, however, expected concurrent needs for other disease conditions and long-term healthcare needs among those with a chronic course would suggest that our estimates are conservative.

There is an urgent need to deploy epidemiological strategies to contain the spread of COVID-19, ${ }^{6}$ with a focus on states with limited healthcare capacity. Concurrently, we may need to expand capacity quickly, possibly through suspension of elective hospitalizations.

Funding: Dr. Khera is supported by the National Center for Advancing Translational Sciences (UL1TR001105) of the National Institutes of Health. The funder had no role in the design and conduct of the study; collection, management, analysis, and interpretation of the data; preparation, review, or approval of the manuscript; and decision to submit the manuscript for publication.

Disclosures: Drs. Krumholz, Ross and Lin work under contract with the Centers for Medicare \& Medicaid Services to develop publicly reported quality measures. Dr. Krumholz was a recipient of a research grant, through Yale, from Medtronic and the U.S. Food and Drug Administration to develop methods for post-market surveillance of 
medRxiv preprint doi: https://doi.org/10.1101/2020.04.01.20050492; this version posted April 3, 2020. The copyright holder for this preprint (which was not certified by peer review) is the author/funder, who has granted medRxiv a license to display the preprint in perpetuity. It is made available under a CC-BY-ND 4.0 International license .

medical devices; is a recipient of a research grant with Medtronic and Johnson \& Johnson, through Yale, to develop methods of clinical trial data sharing; was a recipient of a research agreement, through Yale, from the Shenzhen Center for Health Information for work to advance intelligent disease prevention and health promotion; collaborates with the National Center for Cardiovascular Diseases in Beijing; received payment from the Arnold \& Porter Law Firm for work related to the Sanofi clopidogrel litigation and from the Ben C. Martin Law Firm for work related to the Cook IVC filter litigation; receives payment from the Siegfried \& Jensen Law Firm for work related to Vioxx litigation; chairs a Cardiac Scientific Advisory Board for UnitedHealth; is a participant/participant representative of the IBM Watson Health Life Sciences Board; is a member of the Advisory Board for Element Science, the Advisory Board for Facebook, and the Physician Advisory Board for Aetna; and is the founder of HugoHealth, a personal health information platform and a co-founder of Refactor Health, an enterprise healthcare Al-augmented data management company. Dr. Ross currently receives research support through Yale University from Johnson and Johnson to develop methods of clinical trial data sharing, from the Food and Drug Administration to establish Yale-Mayo Clinic Center for Excellence in Regulatory Science and Innovation (CERSI) program (U01FD005938), from the Medical Device Innovation Consortium as part of the National Evaluation System for Health Technology (NEST), from the Agency for Healthcare Research and Quality (R01HS022882), from the National Heart, Lung and Blood Institute of the National Institutes of Health (NIH) (R01HS025164, R01HL144644), and from the Laura and John Arnold Foundation to establish the Good Pharma Scorecard at Bioethics International and to establish the Collaboration for 
medRxiv preprint doi: https://doi.org/10.1101/2020.04.01.20050492; this version posted April 3, 2020. The copyright holder for this preprint (which was not certified by peer review) is the author/funder, who has granted medRxiv a license to display the preprint in perpetuity. It is made available under a CC-BY-ND 4.0 International license.

Research Integrity and Transparency (CRIT) at Yale. The other authors report no potential conflicts of interest. 
medRxiv preprint doi: https://doi.org/10.1101/2020.04.01.20050492; this version posted April 3, 2020. The copyright holder for this preprint (which was not certified by peer review) is the author/funder, who has granted medRxiv a license to display the preprint in perpetuity.

It is made available under a CC-BY-ND 4.0 International license .

Figure 1: Inpatient bed capacity across US states.

Number of inpatient beds per 10,000 population in 2018, overall (blue), occupied (based on state-wise occupancy rates), intensive care unit (ICU, green) and airborne isolation (yellow).

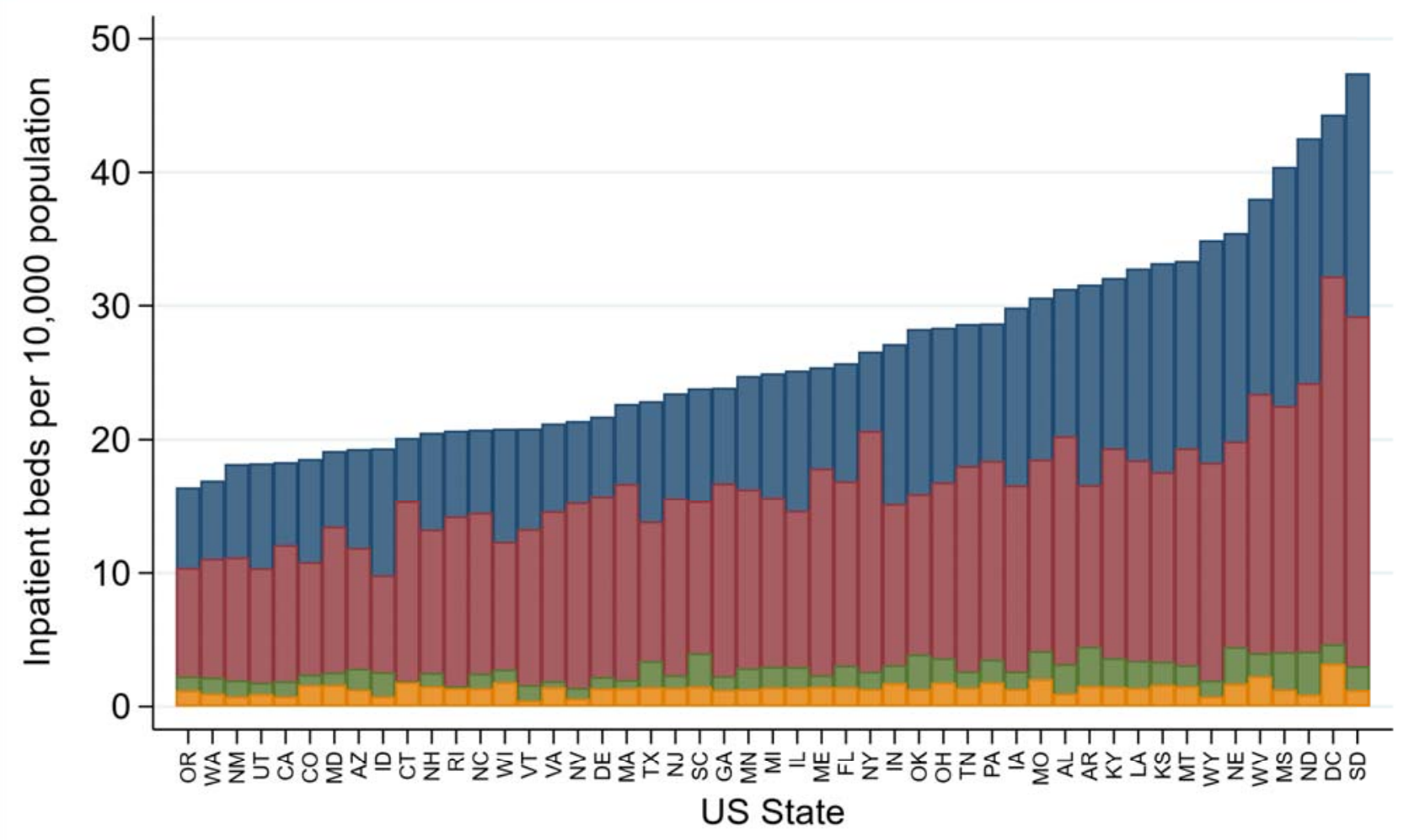

Total beds ICU beds
Occupied beds

Airborne isolation beds 
medRxiv preprint doi: https://doi.org/10.1101/2020.04.01.20050492; this version posted April 3, 2020. The copyright holder for this preprint (which was not certified by peer review) is the author/funder, who has granted medRxiv a license to display the preprint in perpetuity.

\section{Figure 2: State monthly hospitalization rates and hospital capacity}

The percentage of a state's population that can be hospitalized with COVID-19 over a 30-day period before all inpatient beds based on 2018 hospital utilization rates (all available beds in blue) and if $100 \%$ of a state's inpatient beds (in red) are used.

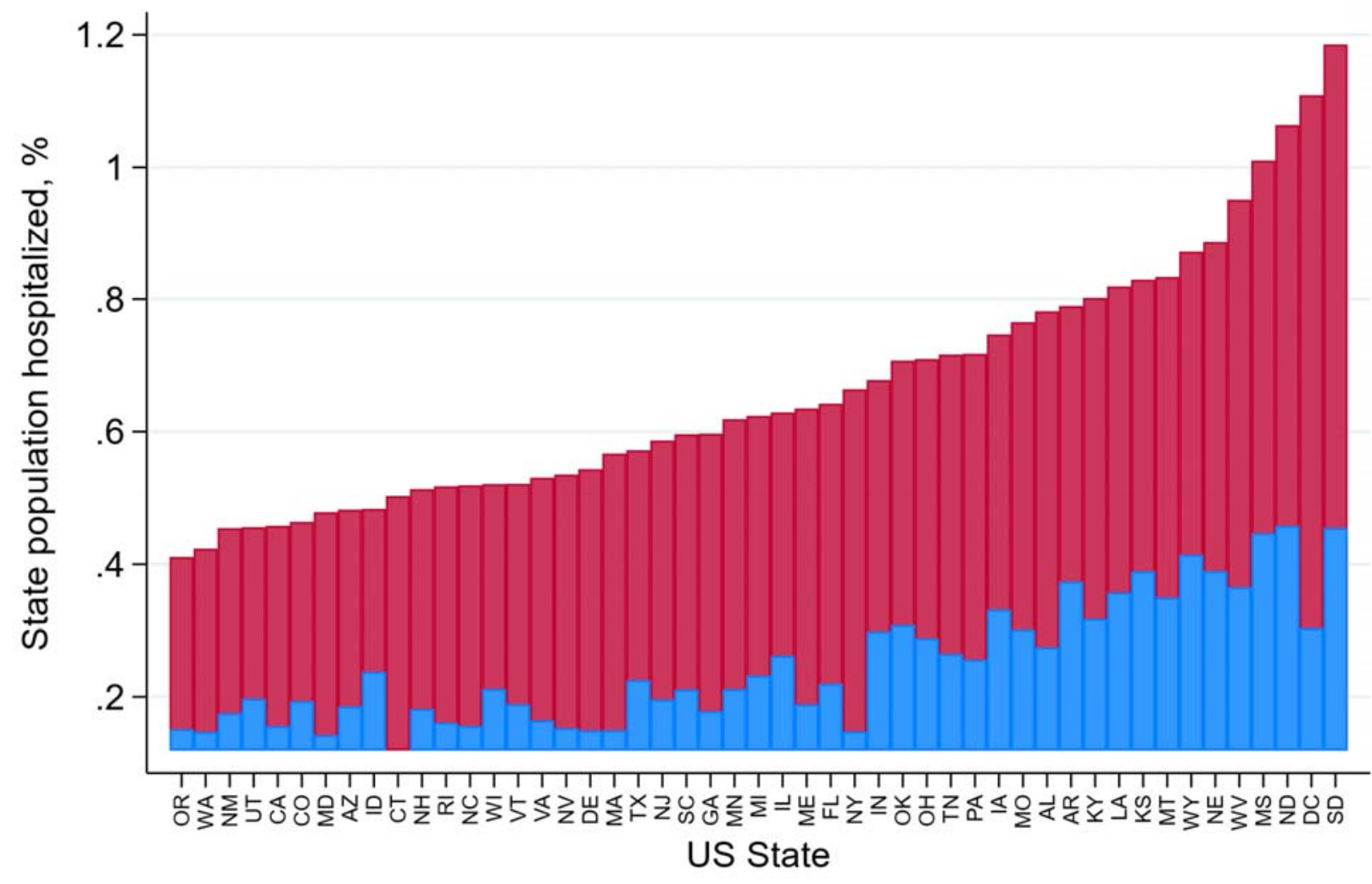

$100 \%$ beds in use

Available beds in use 


\section{References}

1. Wu JT, Leung K, Leung GM. Nowcasting and forecasting the potential domestic and international spread of the 2019-nCoV outbreak originating in Wuhan, China: a modelling study. Lancet. 2020;395(10225):689-697.

2. Wu Z, McGoogan JM. Characteristics of and Important Lessons From the Coronavirus Disease 2019 (COVID-19) Outbreak in China: Summary of a Report of 72314 Cases From the Chinese Center for Disease Control and Prevention. JAMA. 2020.

3. Guan WJ, Ni ZY, Hu Y, et al. Clinical Characteristics of Coronavirus Disease 2019 in China. N Engl J Med. 2020.

4. Centers for Disease Control and Prevention. Coronavirus Disease 2019 (COVID19) in the U.S. Available at: https://www.cdc.gov/coronavirus/2019-ncov/casesin-us.html\#reporting-cases. Accessed March 11, 2020.

5. Paules Cl, Marston HD, Fauci AS. Coronavirus Infections-More Than Just the Common Cold. JAMA. 2020;doi: 10.1001/jama.2020.0757.

6. Anderson RM, Heesterbeek H, Klinkenberg D, Hollingsworth TD. How will country-based mitigation measures influence the course of the COVID-19 epidemic? The Lancet. 2020;doi: 10.1016/S0140-6736(20)30567-5. 